Swiss J. Geosci.

\title{
A new Isochirotherium trackway from the Triassic of Vieux Emosson, SW Switzerland: stratigraphic implications
}

\author{
Marco AvanZini ${ }^{1, *} \&$ Lionel CAVIN ${ }^{2}$
}

Key words: Tetrapod footprint, Isochirotherium, Ichnotaxonomy, Vieux Emosson tracksite, Early Triassic

\begin{abstract}
The footprint assemblage of Vieux Emosson, located at $2400 \mathrm{~m}$ altitude in the Swiss Alps, was first described in 1982. The assemblage was regarded as Late Ladinian or Carnian in age, but the dating was questioned because the taxa show few affinities with other Triassic assemblages. Here we describe a short trackway with shallow but well-preserved tracks referred to the ichnogenus Isochirotherium, showing affinities with Isochirotherium soergeli and Isochirotherium lomasi. The trackway is present on a piece of slab ex situ lying on a mass of fallen rocks, but the slab can be attributed with confidence to the same level as the main one previously mapped. Preliminary observations in situ and of the footprint casts made in 1979 and deposited in the Natural History Museum of Geneva suggest that none of these are attributable to dinosaurs and that the Vieux Emosson footprints are mainly "track preservation variations" of chirotherian tracks. The occurrence of the ichnogenus Isochirotherium favours an older age, probably Early or Middle Triassic, than previously suggested for the Vieux Emosson tracksite.
\end{abstract}

RÉSUMÉ

L'assemblage ichnologique du Vieux Emosson, situé à 2400 mètres d'altitude, a été décrit en 1982. Il a été considéré d'âge Ladinien supérieur ou Carnien, mais la datation a été remise en question car les ichnotaxons n'ont que peu d'affinités avec les autres assemblages du Trias. Dans cet article nous décrivons une courte piste bien préservée, mais peu marquée, qui est attribuée à l'ichnogenre Isochirotherium. Elle présente des affinités avec les espèces Isochirotherium soergeli et Isochirotherium lomasi. La piste est préservée sur un fragment de dalle découvert isolé sur un éboulis. La lithologie du bloc montre qu'il correspond vraisemblablement à une contre-empreinte du niveau principal cartographié en 1979. Cette piste indique un âge pour l'assemblage du Vieux Emosson plus ancien que celui proposé précédemment, probablement Trias inférieur ou Trias Moyen. Des observations préliminaires sur le terrain ainsi que des comparaisons avec des moulages des empreintes conservés au Muséum d'Histoire naturelle de la Ville de Genève semble indiquer qu'aucune d'entre elles n'ont été laissées par des dinosaures. Elles correspondraient à des variations de préservation d'empreintes de Chirotheriidés.

\section{Introduction}

The reptile footprint locality of Vieux Emosson, Valais, southwestern Switzerland, has been discovered in 1976 by Georges Bronner (Bronner \& Demathieu 1977). The discovery of "dinosaur" footprints at high altitude in the Alps aroused public interest and in 1979 a team composed of people from several Swiss and French institutions undertook fieldwork. Three hundred and fifty square meters were mapped (drawings and photographs), and 114 footprints or clusters of footprints were moulded.

The scientific results were published by Demathieu \& Weidmann (1982). They recorded nine ichnospecies on a single footprint-bearing surface: two species were referred to chirotheroids (Brachychirotherium sp., Isochirotherium sp.); four referred to two tridactyl "dinosauroid" ichnogenera, Paratrisauropus (P. mirus Demathieu \& Weidmann 1982, P. bronneri Demathieu \&
Weidmann 1982, P. latus Demathieu \& Weidmann 1982) and Prototrisauropus sp.; one to a tetradactyl reptile (Deuterosauropodopus sedunensis DeMATHIEU \& WEIDMANN 1982); one to a pentadactyl reptile (Pachysaurichnium emossonense DEMATHIEU \& WEIDMANN 1982); and one to a possible bidactyl reptile (Bifidichnium ambiguum DEMATHIEU \& WEIDMANN 1982). However, the identification of the latter taxon was regarded as uncertain. In their study, Demathieu \& Weidmann (1982) referred several footprint morphologies to ichnotaxa described by Ellenberger (1972) from Lesotho. As Haubold (1986) remarked, most of the ichnotaxa coined by Ellenberger (1972) are poorly defined and not compared with taxa from other parts of the world. This observation questions the identification of some of the Vieux Emosson footprints. In their systematic works, Ellenberger (e.g., 1972, 1974) and Demathieu \& Weidmann (1982) favoured splitting rather than lumping (Lockley \& Meyer 2000), a technique that

${ }^{1}$ Museo Tridentino di Scienze Naturali, Via Calepina, 14, 38100 Trento, Italy.

${ }^{2}$ Dpt. de géologie et paléontologie, Muséum de la ville de Genève, C.P. 6434, 1211 Genève 6, Switzerland.

*Corresponding author: Marco Avanzini. E-mail: avanzini@mtsns.tn.it 
may have led to an overestimation of the number of taxa present at the Vieux Emosson site. Meyer \& Thüring (2003) questioned the occurrence of nine ichnospecies at the Vieux Emosson site, and claimed that none of them was made by dinosaurs. They suggested that a revision of these ichnotaxa is necessary, but warned that re-examination of the footprints will be difficult because due to weathering many of the details of the tracks are no longer visible. We agree that a revision is necessary and plan to undertake it in the near future because we have verified that even after 28 years the erosion has not so heavily damaged the footprints.

The aim of the present paper is to describe a short trackway preserved as natural cast on an isolated slab of fine sandstone (discovered in August 2008), and to discuss its stratigraphic implications. We do not attempt here a revision of the ichnotaxa of the Vieux Emosson site, but we only briefly discuss some of the ichnotaxa that have implications for the age of the site.

Institutional abbreviations. - A replica of the described trackway, as well as replicas of isolated footprints from the Vieux
Emosson tracksite described in this paper are housed in the Natural History Museum of Geneva (MHNG).

Other abbreviations. - The terms concerning vertebrate palaeoichnology mainly follow Leonardi (1987). To avoid repetition in the systematic, the authors and years of publication of the ichnotaxa will only be mentioned at the first mention.

\section{Geological setting}

The Vieux Emosson tracksite is located at $2400 \mathrm{~m}$ altitude, in the Mesozoic autochthonous series covering the Aiguilles Rouges Massif (Fig. 1b). This unit was studied by Amberger (1960) and the area surrounding the tracksite was described in greater detail by Demathieu \& Weidmann (1982). In the Scex Blancs profile, a spot situated close to the area mapped in 1979, Amberger (1960) measured 57.4 meters of thickness for the Triassic covering. The sandstone bed containing the
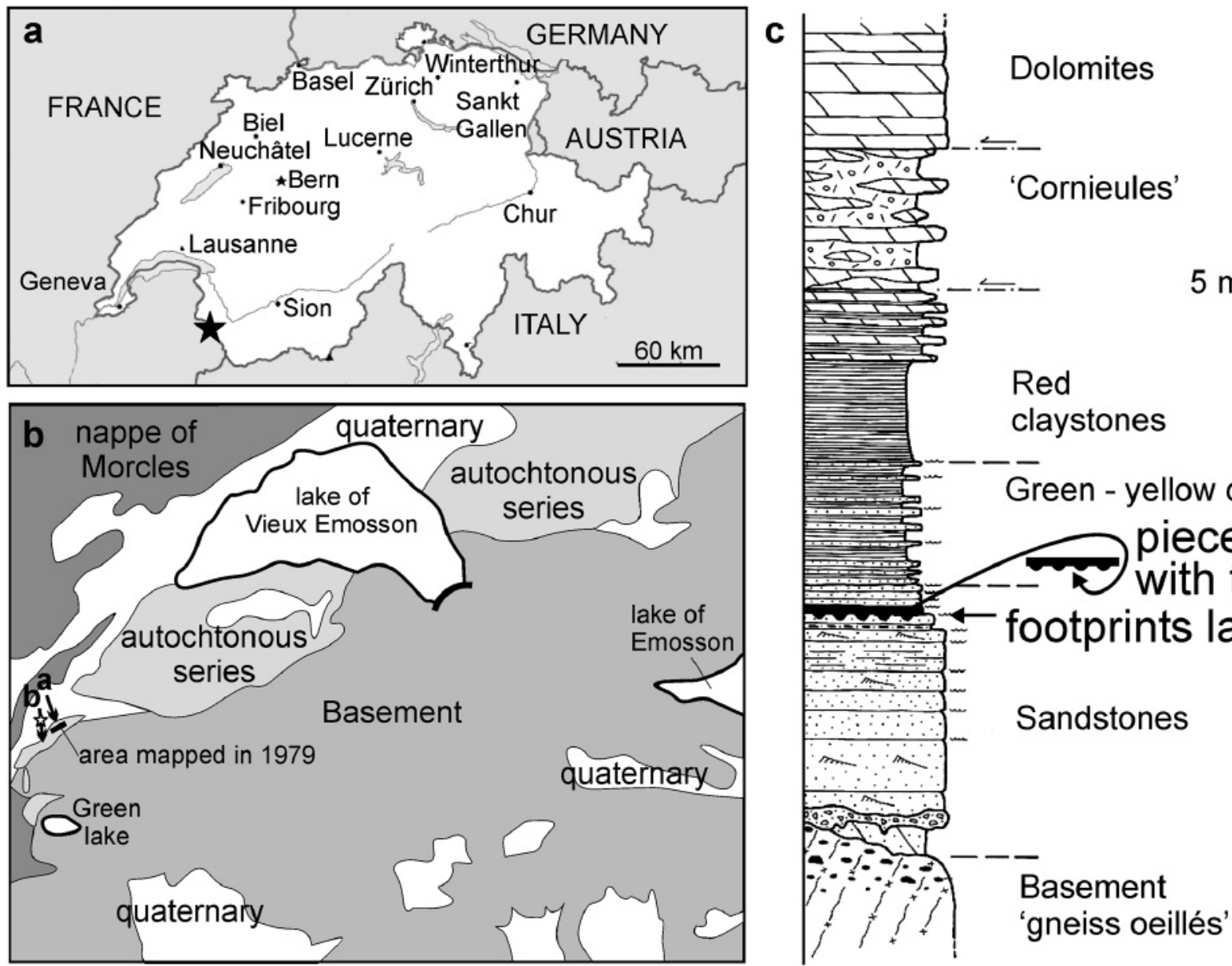

Fig. 1. a) Location of the reptiles footprint tracksite of Vieux Emosson in Switzerland (asterisk); b) geological sketch from the Vieux Emosson area (modified from Demathieu \& Weidmann 1982), with the location of the isolated slab with the Isochirotherium trackway described here (white asterisk), and direction of the views (arrows) shown in figure 2; c) stratigraphy of the trampled layers (modified from Demathieu \& Weidmann 1982), with the original layer of the footprint slab indicated.

2 M. Avanzini \& L. Cavin 
footprints lies within a transgressive sequence of sandstones, shales and dolomites that overlies the "gneiss oeilles" of the basement. The base of the series, below the footprintbearing level, is composed of 4.5 meters of sandstone beds decreasing in thickness upwards. The last bank underneath the footprint-bearing level bears ripple marks on top, is sometimes wrapped with a thin layer of greenish clay, and locally some mud cracks up to $10 \mathrm{~cm}$ in diameter occur. The sedimentological features clearly indicate a palaeoenvironment corresponding to a very shallow body of water, subjected to temporary periods of emersion in a marine-marginal setting. The level with the footprints is on top of a ca. 10 centimetre thick bed of sandstone, cemented with calcite, and covered in some areas with a thin layer of greenish clays and occasionally with ripple marks.

Above the footprint level lies a succession of sandstone and greenish to yellowish clays, covered with a sequence of reddish shale and dolomitized limestone (Fig. 1c). No microfossils and macrofossils, except indeterminate algae and brachiopods in the dolomitized limestone (Amberger 1960), have been recorded so far.

The dating of the series is problematic. Amberger (1960) suggested an Early Triassic (Buntsandstein) age for the basal sandstones of the series (i.e., those with the footprints), on the basis of the lithofacies, which is reminiscent of the facies of the Helvetic Triassic of Glarus and the Buntsandstein of Germany. Demathieu \& Weidmann (1982) noticed that the ichnofauna from Vieux Emosson differs from the Anisian-Ladinian ichnofauna located on the eastern side of the Massif Central (France) by the presence of less chirotheroids and more plant-eater dinosauroids in the former assemblage than in the latter. They concluded that the age of the Vieux Emosson tracksite is younger than Anisian-Ladinian, possibly Late Ladinian or rather Carnian in age. Lucas (2007) accepted this age for the Vieux Emosson assemblage, but without discussion.

The piece of slab with the new footprints is not located in situ (Fig. 2b). The thickness (about 20 centimeters) of the footprint-bearing layer of the slab as well as its lithofacies (fine greenish sandstone) are very similar to the sandstone bed lying directly above the main track-bearing surface of the Vieux Emosson tracksite. Because the tracks of the new trackway are preserved as natural casts (concave epirelief), the slab is an upside down fragment of the beds covering the main track-bearing surface described by Demathieu \& Weidmann (1982).

After a thorough survey of the Triassic outcrops in the Vieux Emosson area, we found no evidence for the occurrence of more than one track-bearing level. The newly discovered slab rests on the mass of fallen rocks at an altitude higher than the surface mapped in 1979 by Demathieu and Weidmann (1982). We looked for the precise spot from which the block was detached but it could not be located. The slab most probably comes from the area located to the south of the area mapped in 1979 (see Demathieu \& Weidmann 1982), which is situated higher in alti- tude and where the main footprint-bearing levels also crop out (Fig. 2).

\section{Paleoichnological description}

The three pedal and two manus footprints are arranged in a short trackway and preserved as natural casts (concave epirelief) (Figs. 3, 4). The morphology of the tracks is variable and the prints are shallow. Manus prints are not clearly marked and have a mostly rounded outline; in one case details of all five digits are recognisable.

Due to the general characteristics of the tracks, they are assigned to:

\section{Reptilia}

Archosauria Cope 1891

Form-Family Chirotheriidae ABEL 1935

Ichnogenus Isochirotherium HAUBOLD 1971

\section{Description}

Pes

Pentadactyl and digitigrades, longer than wide, with a length/ width ratio $=1.8$. Digit $\mathrm{III} \geq \mathrm{II}>\mathrm{I}>\mathrm{IV}>\mathrm{V}$. Digits I-IV are robust and elongated. Digit II is longer than digit IV and is as long as digit III. The total divergence between digits I-IV is $38^{\circ}$. The divarication between digits III and IV is clearly larger when compard to those between digits I and II and between digit II and III; and even the total divarication angle between digit II and IV $\left(25^{\circ}\right)$ is greater than the one between digits I and III $\left(13^{\circ}\right)$. The metatarsal - phalangeal pad of digit IV is connected to the impression of $\mathrm{V}$ by a low ridge formed by the sole underlying the fourth metatarsal. The metatarsal-phalangeal pad of digit $\mathrm{V}$ is well pronounced. The median border of the impression overlaps the extended long axis of digit I. No phalangeal pads and claw imprints are recognisable. (Mean parameters - L: 207 mm; W: 110 mm. Digit length: I: 87 mm, II: 95 mm, III: $100 \mathrm{~mm}$; IV: $82 \mathrm{~mm}$; V: $67 \mathrm{~mm}$. Cross-axis equal to $90^{\circ}$ ).

\section{Manus}

The manus print is located in front and in close proximity to the pes and the axis of digit II of the manus has the same orientation as the axis of digit III of the pes. The manus is pentadactyl and digitigrade. There is a small difference in the length of digits II and III and both are longer than digits I and IV. Digit V is small and separated from digits I-IV group which is incomplete. Digits II, III and IV are at their proximal ends fused into a metatarsal-phalangeal pad. Divergence I-IV: $55^{\circ}$, divergence I-V: $95^{\circ}$. The (manus lenth/pes length)-ratio is about 0.5 .

(Mean parameters - L: 110; W: $82 \mathrm{~mm}$. Digit length: I: 50 mm, II: 60 mm, III: 65 mm; IV: 45 mm; V: ?32 mm) 

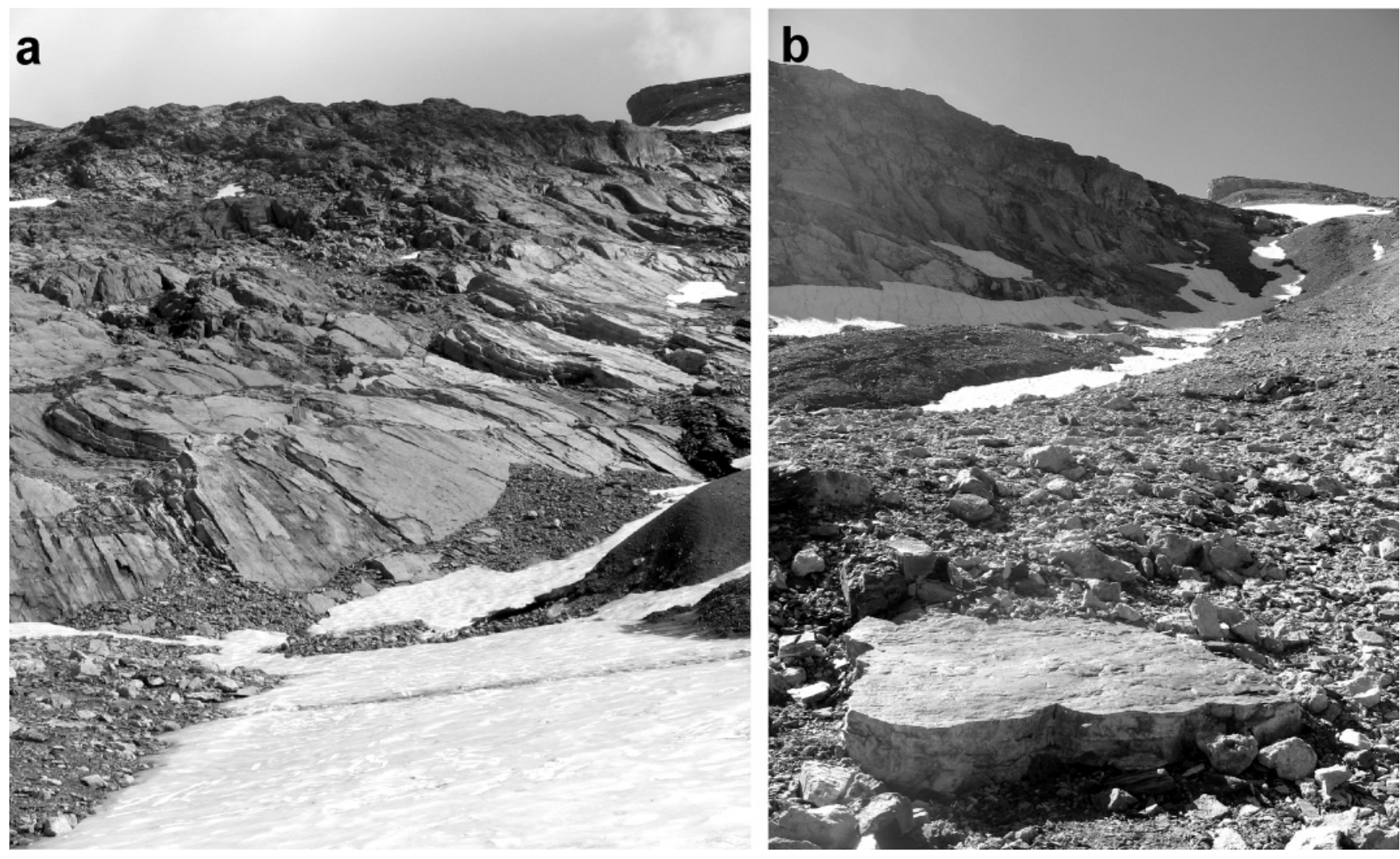

Fig. 2. a) Autochthonous, sedimentary Triassic covering the "gneiss oeillés" of the basement of the Aiguilles Rouges Massif. The area mapped in Demathieu \& Weidmann (1982) is located in the centre of the photograph. The isolated slab with the trackway described in this paper is located outside and to the right of this photograph. View is towards the SE. b) The fallen slab with the Chirotherium trackway described in this paper. The Triassic sandstone, where the slab is coming from, is visible on the left of the photograph, just above the snow field. View towards the SSE.

\section{Trackway}

Three pes footprints are aligned in a trackway (Fig. 3). The mean value for the oblique pace is $53.7 \mathrm{~cm}$ with a slightly negative (sensu Leonardi 1987) divarication angle of about $2^{\circ}$ in respect to the trackway midline. The pace angle is about $170^{\circ}$. The position of the manus with respect to the pes is variable. Generally, it is slightly outward rotated and situated immediately in front of the pes digit III or slightly on the inside of the trackway.

\section{Discussion}

\section{Ichnotaxonomy}

Due to the slightly greater length of pes digit III $(10 \mathrm{~cm})$ in respect to II $(9.5 \mathrm{~cm})$ and the relationship between the other digits (III $\geq \mathrm{II}>\mathrm{I}>\mathrm{IV}>\mathrm{V}$ ), the footprints can be assigned to the ichnogenus Isochirotherium formalised by Haubold in 1971. The characteristics of this ichnogenus are (1) a pes with relatively long digits II and III and with a digit V shorter than digit I; (2) the base of digit V located within the digits I-IV; (3) the distal phalanges of digit V not very pronounced; (4) a manus smaller than the pes; (5) a pace angulation of around $165^{\circ}$; and (6) a difference in the outward rotation of pes and manus of about $20^{\circ}$ (Haubold 1971). Possible trackmakers of this ichnogenus are crurotarsans (Haubold 1971b, 1894, 1986, Haubold \& Klein 2002).

The relatively large dimensions of the new footprints from Vieux Emosson suggest that they were left by one of the larger sized ichnospecies of the ichnogenus Isochirotherium. Nevertheless, among the larger forms no known ichnospecies possess comparable characteristics. Isochirotherium herculis EGERTON, 1839 is a large chirotheroid with a pes longer than $30 \mathrm{~cm}$. Digit II has almost the same length as digit III and is sometimes even longer. The angle between digit I and IV is greater than $50^{\circ}$ and the cross axis is close to $80^{\circ}$. The width of the group I-IV is larger than long. The type species comes from the British Anisian (Tarpoley Siltstone - Sherwood Sandstone Group; Treasise \& Sarjeant 1997). It is a form that appears to be more robust, with a slightly wider I-IV group, than the form studied here. In the Middle Anisian ichnospecies Isochirotherium marshalli PEABODY, 1948 the pes is characterised by rather short digits. The base of the digits II-III forms a metatarsal-phalangeal pad, as can also be observed in Chirotherium barthi KAUP, 1835. The posterior border of digit

4 M. Avanzini \& L. Cavin 


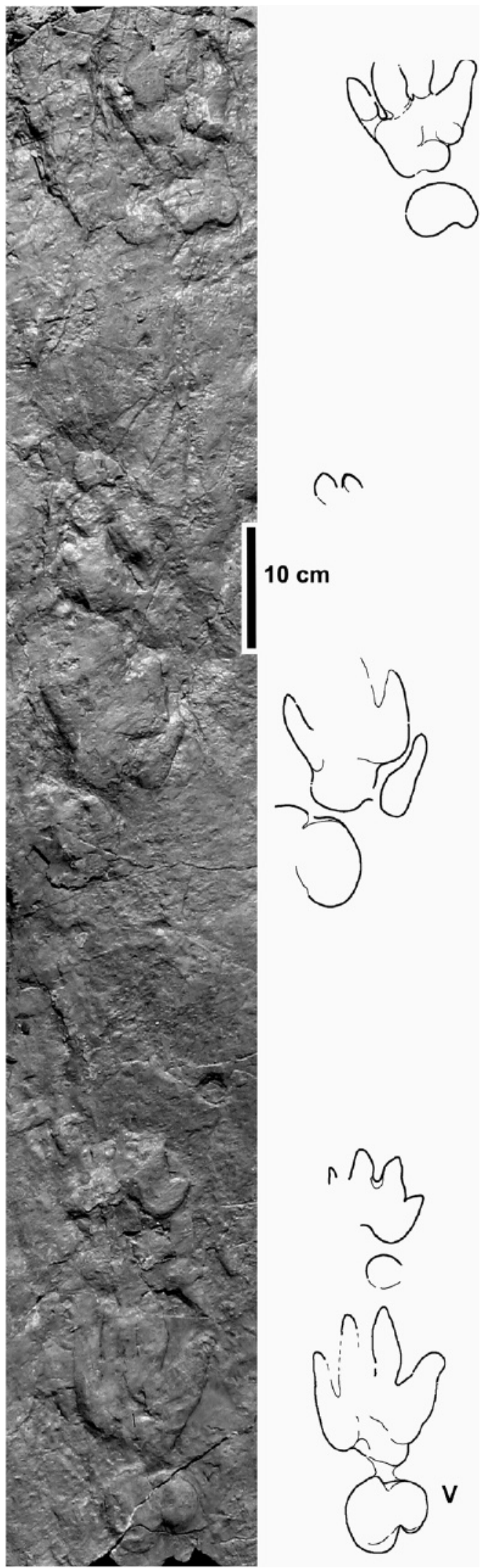

Fig. 3. Photograph (left) and interpretative drawing (right) of the new Isochirotherium $\mathrm{sp}$. trackway.

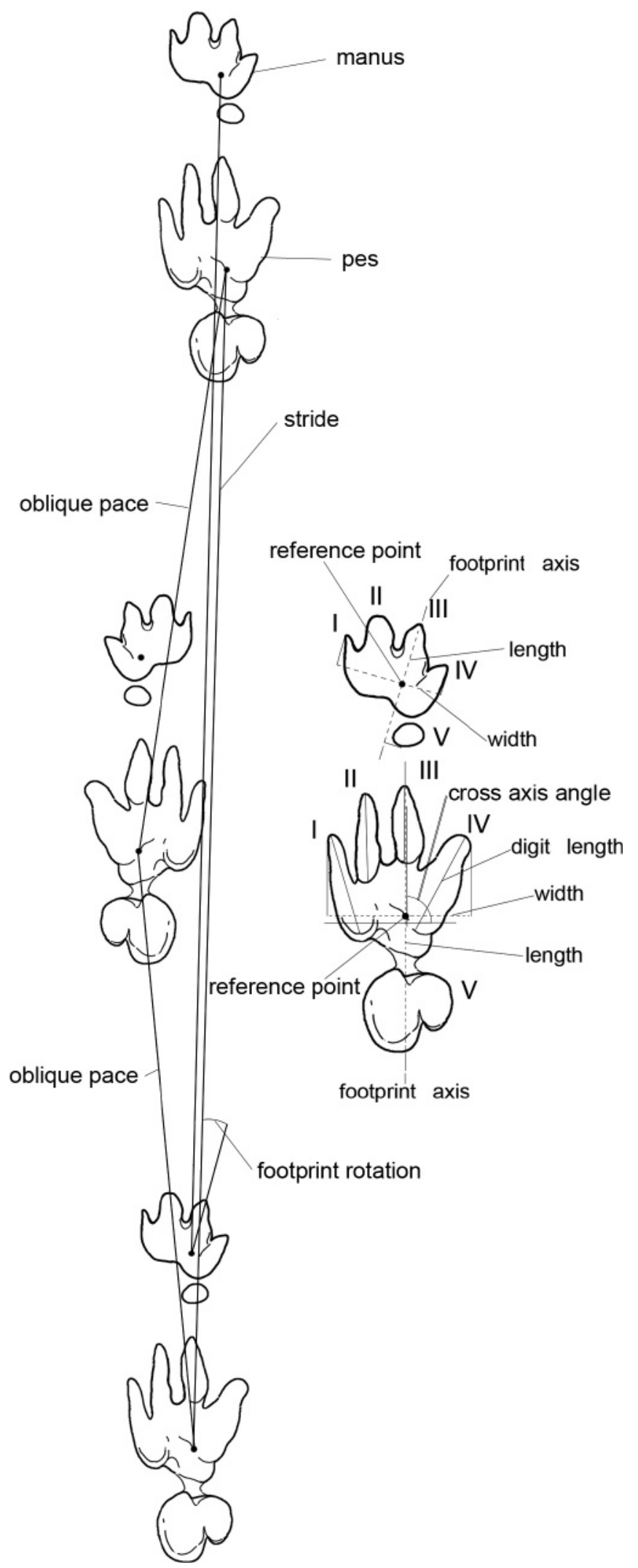

Fig. 4. Schematic Isochirotherium sp. trackway and footprints illustrating the measured parameters. 


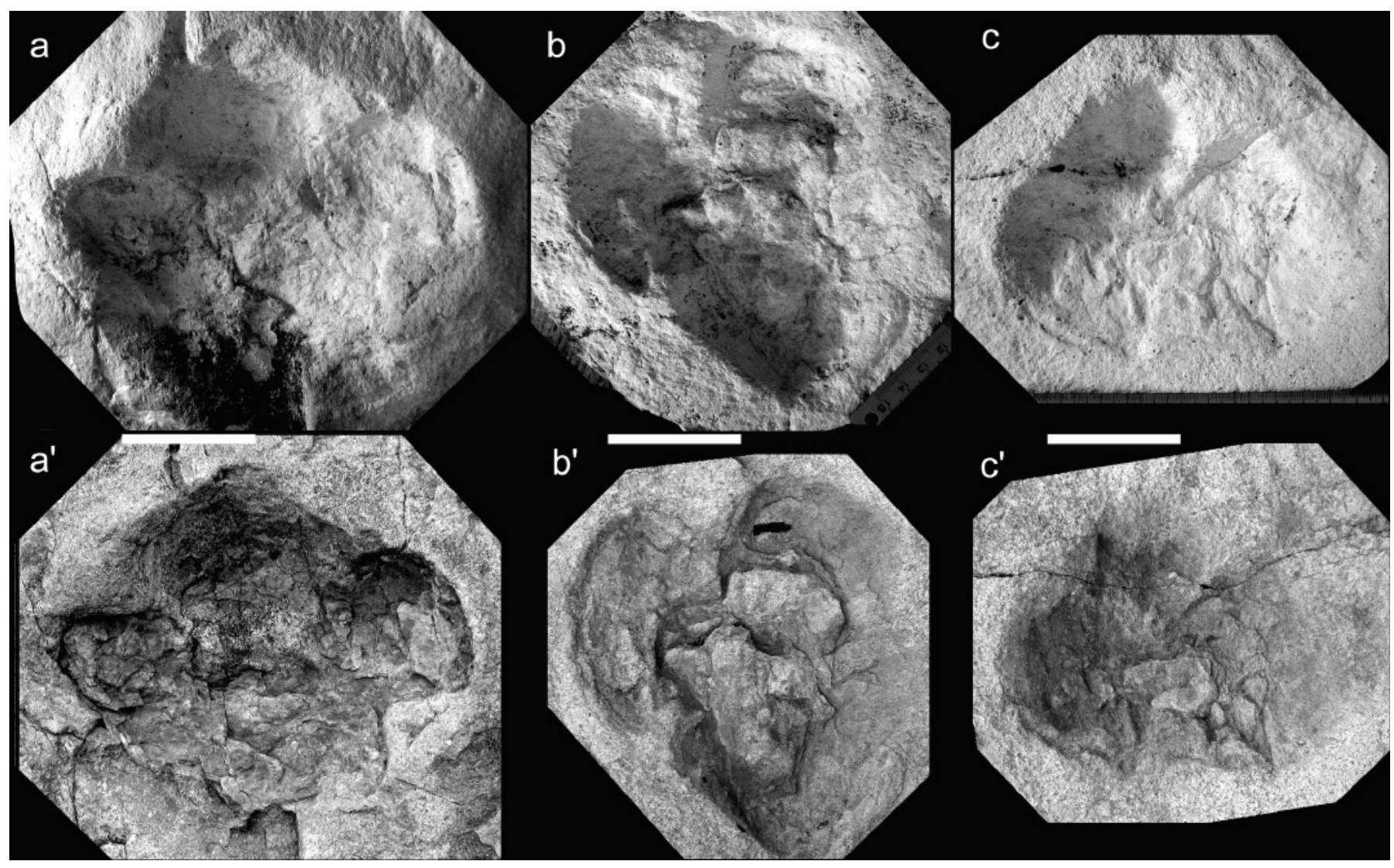

Fig. 5. Photographs of the holotypes of the three Paratrisauropus ichnospecies described from the Vieux Emosson tracksite by Demathieu \& Weidmann (1982). a) P. latus Demathieu \& Weidmann 1982 (MHNG n 110). b) P. bronneri Demathieu \& Weidmann 1982 (MHNG $n^{\circ} 89$ ). c) P. mirus Demathieu \& WeidmanN 1982 (MHNG n ${ }^{\circ}$ 5). a, b, c: photographs of the casts made in September 1979. a', b', c': photographs (made in situ in August 2007) of the genuine footprints shown in a-c. Scale bars: $50 \mathrm{~mm}$. Note that even after 28 years, erosion has not substantially damaged the footprints, even if some blurring is visible.

group I-IV is broadly indented between the base of digit I and V. The divarication between digits I and IV is $40^{\circ}$. The phalangeal portion of digit $\mathrm{V}$ seems much smaller in respect to the large ovoidal shaped metatarsal-phalangeal pad of the same digit that is clearly larger than in other chirotherian ichnotaxa. These are all characteristics that make this new trackway very different from the previously described material from Vieux Emosson (Demathieu \& Weidmann 1982). The similarity and possible synonymy of I. marshalli with other Middle Triassic Isochirotherium ichnospecies such as I. coureli DeMATHIEU, 1970; I. hessebergense HAUBOLD, 1984; and I. inferni AvANZINI \& LEONARDI, 2002 has recently been pointed out by Diedrich (2007). However, none of these forms are comparable with the new trackway from Vieux Emosson, but they are instead very similar to Isochirotherium soergeli HAUBOLD, 1967 that was the first representative of the "small manus" group of chirotheria recognised from the Buntsandstein (Olenekian) (Haubold 1967). The dimensions of the feet of the holotype are much smaller than in our specimens (they vary from 4 to $15 \mathrm{~cm}$ ) but the morphological characteristics are very similar. Digit IV of the foot is much longer than I. Digit II and III are almost simi- lar in size. The cross-axis is close to $90^{\circ}$ and the external digit has a divergence angle between $30^{\circ}$ and $40^{\circ}$.

The only other similar form is Isochirotherium lomasi BAIRD, 1954 from the British Anisian, with pes prints close to $18 \mathrm{~cm}$ long, a group I-IV longer than wide, and with a slender outline. The Isochirotherium lomasi trackway shows, however, a small manus print and a pronounced outward rotation from the midline (King et al. 2005) that is different from the new Vieux Emosson trackway.

Because of a lack of enough coinciding morphological parameters with other representatives of this group, we do not suggest any substantial morphological conformity and do not propose any further possible attribution.

\section{Comments on the identification of dinosauroid and brachychiroid ichnotaxa by Demathieu \& Weidmann (1982)}

The purpose here is not to make a revision of these ichnotaxa described in 1982, but we conduct some observations on these footprints in order to assess their importance in the discussion about the age of the tracksite.

6 M. Avanzini \& L. Cavin 


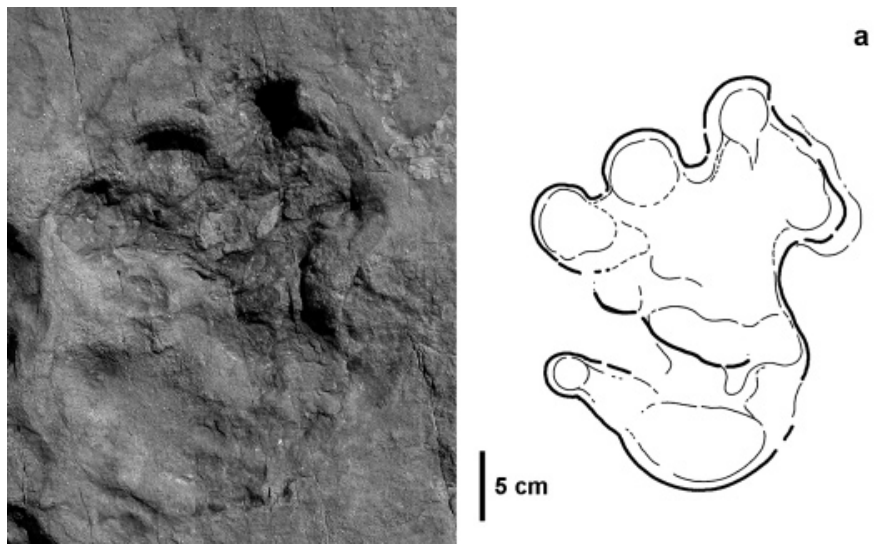

Demathieu \& Weidmann (1982) mentioned the presence of dinosauroid footprints at Vieux Emosson, which they assigned to three Paratrisauropus ichnospecies (Fig. 5), to Prototrisauropus Ellemberger 1972 ichnogenus, and to Deuterosauropus sedunensis DEMATHIEU \& WEIDMANN 1982 (Fig. 6) and Pachysaurichnium emossoense DEMATHIEU \& WEIDMANN 1982. They distinguished the three ichnospecies of Paratrisauropus on the basis of qualitative characters as well as on statistic comparisons of morphometric parameters. However, there are some limitations in the distinction of these three ichnospecies for the following reasons:

1) Most of the footprints of the three compared samples do not belong to trackways. Exceptions are $\mathrm{n}^{\circ} 51$ and 52, and 57 and 58 that belong to two trackways of $P$. mirus DEMATHIEU \& WEIDMANN 1982; ${ }^{\circ} 68$, and 87 and 88 that belong to two trackways of $P$. bronneri DeMATHIEU \& WEIDMANN $1982 ; \mathrm{n}^{\circ} 71$ and 74 that belong to a trackway of $P$. latus DEMATHIEU \& WEIDMANN 1982. However, we think that these trackways are not obvious because they are located in heavily "dinoturbated" areas. Consequently, the making of the

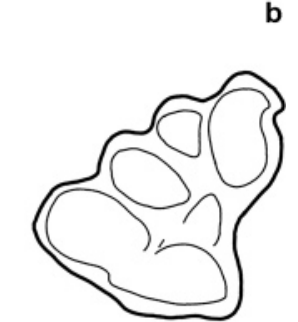

Fig. 6. Deuterosauropus sedunensis Demathieu \& WEIDMANN, 1982 footprint 42 (b) reinterpreted as a poorly-preserved chirotheroid track (a).

three clusters of footprints, before performing the statistic assessment of their morphometric differences, appears arbitrary to us. Also Demathieu \& Weidmann (1982) recognised that $P$. bronneri and $P$. latus are rather close and might constitute a continuum.

2) We consider that the range of variation of the footprint morphology between the three species of Paratrisauropus enter in the range of variation of the footprint morphology made by a single individual in different substrate consistency as shown in experimental ichnology (e.g., Milàn 2006; Milàn \& Broomley 2006).

Demathieu \& Weidmann (1982) also mentioned the occurrence of two chirotheroid ichnogenera in the Vieux Emosson assemblage. These are Brachychirotherium sp. and Isochirotherium sp., both represented by a few footprints only (Fig. 7). By studying the casts and the footprints in situ, we are not able to observe the diagnostic characters (especially number and proportions of toes) quoted by Demathieu \& Weidmann (1982) to identify these genera, and consequently we question the occurrence of Brachychirotherium in the Vieux Emosson
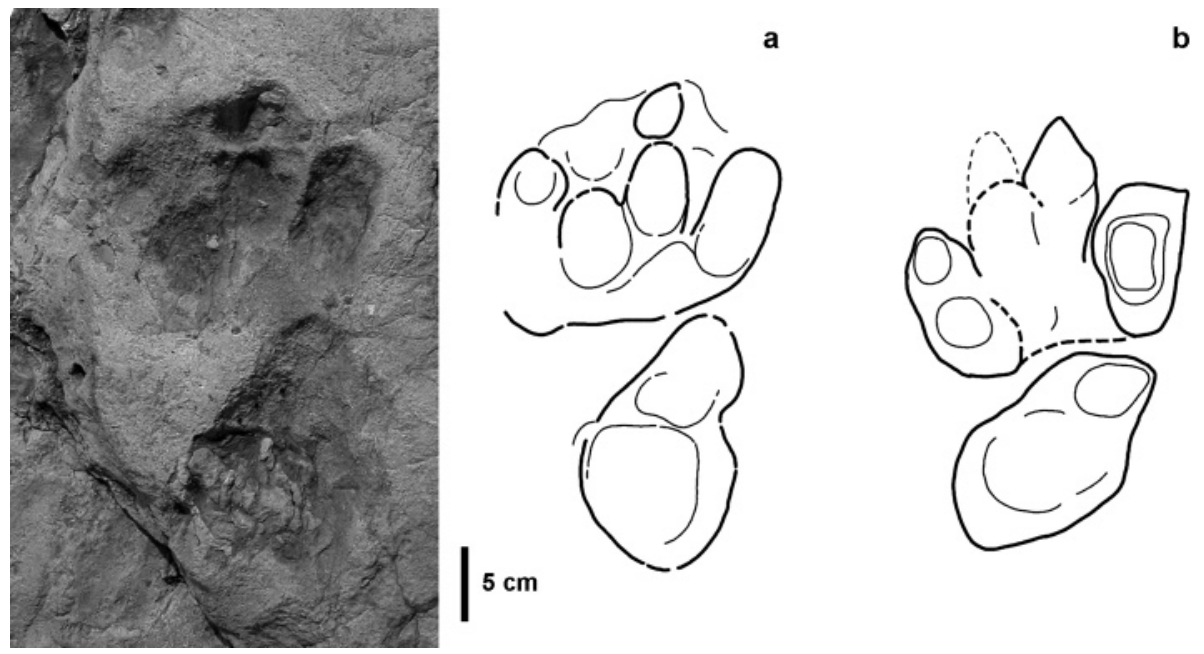

Fig. 7. A possible Isochirotherium sp. track (footprint 22) (a) from the main outcrop compared to Isochirotherium sp. footprint 96 (b) described by Demathieu \& Weidmann (1982). 
assemblage, and the identification of Isochirotherium based on the footprints studied in 1979. In particular, the five footprints referred to Isochirotherium sp. by Demathieu \& Weidmann (1982) are not very similar to the Isochirotherium footprints described in this paper, because they are broader than the new footprints. However, this again could be a substrate-, behavioural-, or preservational-controlled feature (Fig. 7).

\section{Age of the Vieux Emosson tracksite}

Demathieu \& Weidmann (1982) suggested that the footprints of Vieux Emosson are younger (i.e., Anisian-Ladinian) than those from the western border of the French Massif Central (Demathieu 1970, 1977; Demathieu \& Demathieu 2004) because of the presence of numerous dinosauroid tridactyl footprints, which they assigned to the ichnogenus Paratrisauropus. They referred one, $P$. mirus, of these three ichnospecies to either a saurischian or ornithischian dinosaur, and the other two, $P$. bronneri and $P$. latus, with caution to a rather large ornithischian. They identified ornithischians as possible trackmakers because of the presence of three digits and because of the rounded extremities of these digits, regarded as evidence of thick, rounded nails. They remarked, however, that the occurrence of this morphotype at Vieux Emosson is surprising, because this typical ornithischian foot morphology is known from bone remains from the Cretaceous only.

Ellenberger (1972) also suggested that the ichnotaxon Paratrisauropus has been made by ornithischian dinosaurs. This hypothesis was adopted by Haubold (1986) and Knoll (2004) without comments, but Irims et al. (2007) questioned this assignation because these footprints show no ornithischian synapomorphies.

However, on the basis of our observations made in situ at Vieux Emosson and on the casts fabricated in 1979 and deposited in the Natural History Museum of Geneva, we question the validity of the three ichnospecies of Paratrisauropus and accordingly exclude the possibility that these footprints have been made by several species of ornithischian-like dinosaurs. We suggest that these footprints (Figs. 6,7) are instead mainly "track preservation variations" of chirotherian tracks. Consequently, there is no reason to suppose, on the basis of the faunal composition, that the Vieux Emosson tracksite is younger than Early to Middle Triassic.

As demonstrated by several authors (Haubold 1986; Demathieu \& Haubold 1972, 1974; Olsen 1983; Lockley \& Hunt 1995; Hunt \& Lucas 2007a, b; Klein \& Haubold 2007; Lucas 2007; Lucas \& Tanner 2007) archosaur footprints show a distinct stratigraphic distribution pattern (limited temporal ranges) that could be useful for biostratigraphy and biochronology of the Triassic.

The tetrapod ichnoassemblages dominated by archosaur tracks of the chirothere morphological group are mainly Early to Middle Triassic in age and all the currently known data indicate that Isochirotherium spans the Olenekian - Anisian and disappears before the end of the Ladinian (Haubold 1971a, b;
Fuglewicz et al. 1990; Ptaszynski 2000; Peabody 1948; Tresise \& Sarjeant 1997, King et al. 2005; Demathieu 1970; Courel \& Demathieu 1976; Gand 1976, 1979a, b; Haubold \& Klein 2002; Avanzini \& Lockley 2002; Karl \& Haubold 1998, 2000; Lucas 2003; Klein \& Haubold 2004, 2007; Klein et al. 2006; Lucas \& Sullivan 2006).

\section{Concluding remarks}

At the Vieux Emosson tracksite the occurrence of Isochirotherium with a very similar morphology as the Early Triassic (Buntsandstein) forms, and the doubtful identification of three Paratrisauropus ichnospecies with their disputable dinosaurian (ornithischian) origin question the Ladinian - Carnian age as suggested by Demathieu \& Weidmann (1982). Hence, we rereconsider an Early Triassic age for the footprint-bearing sandstones of the Vieux Emosson tracksite, as initially proposed by Amberger (1960).

\section{Acknowledgements}

The authors thank Christian A. Meyer (Natural History Museum Basel) for his suggestion for the Early Triassic age of the Vieux Emosson tracksite and for comments on a first draft of the manuscript. We thank Spencer G. Lucas (New Mexico Museum of Natural History and Science, Albuquerque) and Hartmut Haubold (Martin-Luther-Universität, Halle) for reviewing this manuscript.

\section{REFERENCES}

Amberger, G.F. 1960: L'autochtone de la partie nord-ouest du massif des Aiguilles Rouges (Haute Savoie et Valais). Unpublished PhD Thesis University of Geneva, $103 \mathrm{pp}$.

Avanzini, M. \& Leonardi, G. 2002: Isochirotherium inferni ichnosp. n. in the Upper Anisian (Illyrian) of Adige Valley (Bozen, Italy). Bollettino Società Paleontologica Italiana 41, 41-50.

Avanzini, M. \& Lockley, M. 2002: Middle Triassic archosaur population structure: interpretation based on Isochirotherium delicatum fossil footprints (Southern Alps, Italy). Palaeogeography, Palaeoclimatology, Palaeoecology 185, 391-402.

Baird, D. 1954: Chirotherium lulli, a pseudosuchian reptile from New Jersey. Museum of Comparative Zoology Bulletin 111, 165-192.

Bronner, G. \& Demathieu, G. 1977: Premières traces de reptiles archosauriens dans le Trias autochtone des Aiguilles Rouges (Col des Corbeaux, Vieil Emosson, Valais, Suisse). Conséquences paléogéographiques et chronostratigraphiques. Comptes rendus de l'Académie des Sciences (Paris) 285D, 649-652.

Courel, L. \& Demathieu, G. 1976: Une ichnofaune reptilienne remarquable dans les grès Triassique de Largentière (Ardèche, France). Palaeontographica A 151, 194-216.

Demathieu, G. 1970: Les empreintes de pas de vertébrés du Trias de la bordure Nord-Est du Massif Central. Cahiers de Paléontologie, Paris, 211 pp.

Demathieu, G. 1977: La palichnologie des Vertébrés. Développement récent et rôle dans la stratigraphie du Trias. Bulletin du Bureau de Recherches Géologiques et Minières 4 (3), 269-278.

Demathieu, G. \& Demathieu, P., 2004: Chirotheria and other ichnotaxa of the European Triassic. Ichnos 11, 79-88.

Demathieu, G. \& Haubold, H. 1972: Stratigraphische Aussagen der Tetrapodenfährten aus der terrestrischen Trias Europas. Geologie 21, 802 836.

Demathieu, G. \& Haubold, H. 1974: Evolution und Lebensgemeinschaft terrestrischer Tetrapoden nach ihren Fährten in der Trias. Freiberger Forschungshefte C 298, 51-72.

8 M. Avanzini \& L. Cavin 
Demathieu, G. \& Weidmann, M. 1982: Les empreintes de pas de reptiles dans le Trias du Vieux Emosson (Finhaut, Valais, Suisse). Eclogae geologicae Helvetiae 75, 721-757.

Diedrich, C. 2007: Millions of reptile tracks - Early to Middle Triassic carbonate tidal flat migration bridges of Central Europe - reptile immigration into the Germanic Basin. Palaeogeography, Palaeoclimatology, Palaeoecology 259, 410-423.

Egerton, P.G. 1839: On two Casts in Sandstone of impression of the Hind Foot of a gigantic Cheirotherium, from the New Red Sandstone of Cheshire. The London and Edinburgh Philosophical Magazine and Journal of science, 3rd series 14(75), 151-158.

Ellenberger, P. 1972: Contribution à la classification des pistes de vertébrés du Trias: Les types du Stormberg d'Afrique du Sud (I partie). Palaeovertebrata, Mémoire Extraordinaire, Montpellier, 117 pp.

Ellenberger, P. 1974: Contribution à la classification des Pistes de Vertébrés du Trias: Les types du Stormberg d'Afrique du sud. (II partie). Le Stormberg supérieur - I. Le biome de la zone B/1 ou niveau de Moyeni: ses biocénoses. Paleovertebrata, Mémoire extraordinaire, Montpellier. $147 \mathrm{pp}$.

Fuglewicz, R., Ptaszynski, T. \& Rdzanek, K. 1990: Lower Triassic footprints from the Swietokrzyskie (Holy Cross) Mountains, Poland. Acta Palaeontologica Polonica 35, 109-164.

Gand, G. 1976: Présentation de deux nouveaux assemblages à traces de reptiles des grès triasiques du plateau d'Antully (Autunois, France). Bulletin de la Société d'Histoire Naturelle d'Autun 79,15-18.

Gand, G. 1979a: Note sur quelques nouvelles pistes de reptiles observées dans le Trias moyen du Plateau d'Antully (Saône-et-Loire - France). Bulletin de la Société d'Histoire Naturelle d'Autun 92,7-20.

Gand, G. 1979b: Description de deux nouvelles traces d'Isochirotherium observées dans les grès du Trias moyen de Bourgogne. Bulletin de la Société d'Histoire Naturelle du Creusot 37, 13-25.

Haubold, H. 1967: Eine Pseudosuchier- Fährtenfauna aus dem Buntsandstein Südthüringens. Hallesches Jahrbuch für Mitteldeutsche Erdgeschichte 8 (1966), 12-48.

Haubold, H. 1971a: Ichnia Amphibiorum et Reptiliorum fossilium. In: Kuhn, O. (Ed.): Handbuch der Paläoherpetologie 18. G. Fischer Verlag, Stuttgart, $124 \mathrm{pp}$.

Haubold, H. 1971b: Die Tetrapodenfährten des Buntsandsteins in der deutschen Demokratische Republik und in Westdeutschland und ihre Äquivalente in der gesamten Trias. Paläontologische Abhandlungen 4 (3), 395-660.

Haubold, H. 1984: Saurierfährten. Die Neue Brehm-Bucherei, A. Ziemsen, Wittenberg. Lutherstadt, $231 \mathrm{pp}$.

Haubold, H. 1986: Archosaur footprints at the terrestrial Triassic-Jurassic transition. In: Padian, K. (Ed.): The beginning of the age of dinosaurs. Cambridge University Press, New York, 189-201.

Haubold, H. \& Klein, H. 2002: Chirotherien und Grallatoriden aus der Unteren bis Oberen Trias Mitteleuropas und die Entstehung der Dinosauria. Hallesches Jahrbuch für Geowissenschaften B 24, 1-22.

Hunt, A.P. \& Lucas, S.G. 2007a: Late Triassic tetrapod tracks of western North America. New Mexico Museum of Natural History and Science Bulletin $40,215-230$.

Hunt, A.P. \& Lucas, S.G. 2007b: The Triassic tetrapod track record. Ichnofaunas, ichnofacies and biochronology. In: Lucas, S.G. \& Spielmann, J.A. (Eds.): The Global Triassic. New Mexico Museum of Natural History and Science Bulletin 41, 78-87.

Irmis, R.B., Parker, W.G., Nesbitt, S.J. \& Liu, J. 2007: Early ornithischian dinosaurs: the Triassic record. Journal of the History of Biology 19, 3-22.

Karl, C. \& Haubold, H. 1998: Brachychirotherium aus dem Coburger Sandstein (Mittlerer Keuper, Karn/Nor) in Nordbayern. Hallesches Jahrbuch für Geowissenschaften B 20,33-58.

Karl, C. \& Haubold, H. 2000: Saurierfährten im Keuper (Obere Trias) Frankens, die Typen von Brachychirotherium. Berichte der Naturwissenschaftlichen Gesellschaft Bayreuth 24, 91-120.

Kaup, J.J. 1835: Mitteilung über Tierfärthen bei Hildburghausen. Neues Jahrbuch für Mineralogie, Geologie und Paläontologie, 1835, 327-328.
King, M.J., Sarjeant, W.A.S., Thompson, D.B. \& Tresise, G. 2005: A revised systematic ichnotaxonomy and review of the vertebrate footprint ichnofamily Chirotheriidae from the British Triassic. Ichnos 12, 241-299.

Klein, H. \& Haubold, H. 2004: Überlieferungsbedingte Variation bei Chirotherien und Hinweise zur Ichnotaxonomie nach Beispielen aus der Mittel- bis Ober-Trias (Anisium-Karnium) von Nordbayern. Hallesches Jahrbuch für Geowissenschaften B 26, 1-15.

Klein, H. \& Haubold, H. 2007: Archosaur footprints - Potential for biochronology of Triassic continental sequences. In: Lucas, S.G. \& Spielmann, J. A. (Eds.): The Global Triassic. New Mexico Museum of Natural History and Science Bulletin 41,120-130.

Klein, H., Lucas, S.G. \& Haubold, H. 2006: Tetrapod track assemblage of the Redonda Formation (Upper Triassic, Chinle Group) in east-central New Mexico - re-evaluation of ichnofaunal diversity from studies of new material. In: Harris, J.D., Lucas, S.G., Spielmann, J.A., Lockley, M.G., Milner, A.R.C. \& Kirkland, J.I. (Eds.): The Triassic-Jurassic terrestrial transition. New Mexico Museum of Natural History and Science Bulletin 37, 241-250.

Knoll, F. 2004: Review of the tetrapod fauna of the "Lower Stormberg Group" of the main Karoo Basin (southern Africa): implication for the age of the Lower Elliot Formation. Bulletin de la Société Géologique de France 175, 73-83.

Leonardi, G. 1987: Glossary and manual of tetrapod footprint palaeoichnology. Departamento Nacional de Produção Mineral, Brasília, 117 pp.

Lockley, M.G. \& Hunt, A.P. 1995: Dinosaur tracks and other fossil footprints of the western United States. Columbia University Press, New York, $338 \mathrm{pp}$.

Lockley, M.G. \& Meyer, C.A. 2000: Dinosaur tracks and other fossil footprints of Europe. Columbia University Press, New York, 323 pp.

Lucas, S.G. 2003: Triassic tetrapod footprint biostratigraphy and biochronology. Albertiana 28, 75-84.

Lucas, S.G. \& Sullivan, R.M. 2006: Tetrapod footprints from the Upper Triassic Passaic Formation near Graterford, Montgomery County, Pennsylvania. In: Harris, J.D., Lucas, S.G., Spielmann, J.A., Lockley, M.G., Milner, A.R.C. \& Kirkland, J.I. (Eds.): The Triassic-Jurassic terrestrial transition. New Mexico Museum of Natural History and Science Bulletin $37,251-256$.

Lucas, S.G. 2007: Tetrapod footprint biostratigraphy and biochronology. Ichnos $14,5-38$.

Lucas, S.G. \& Tanner, L.H. 2007: The nonmarine Triassic-Jurassic boundary in the Newark Supergroup of eastern North America. Earth-Science Reviews $84,1-20$

Meyer, C.A. \& Thüring, B. 2003: Dinosaurs of Switzerland. Comptes Rendus Palevol 2, 103-117.

Milàn, J. 2006: Variations in the morphology of emu (Dromaius novaehollandiae) tracks reflecting differences in walking pattern and substrate consistency: ichnotaxonomic implications. Palaeontology 49, 405-420.

Milàn, J. \& Bromley, R.G. 2006: True tracks, undertracks and eroded tracks, experimental work with tetrapod tracks in laboratory and field: Palaeogeography, Palaeoclimatology, Palaeoecology 231, 253-264.

Olsen, P.E. 1983: Relationship between biostratigraphic subdivisions and igneous activity in the Newark Supergroup. Geological Society of America, Abstracts with Programs 15, p. 93.

Peabody, F.E. 1948: Reptile and amphibian trackways from the Lower Triassic Moenkopi formation of Arizona and Utah. Bulletin of the Department of Geological Sciences 27, 295-468.

Ptaszynski, T. 2000: Lower Triassic vertebrate footprints from Wióry, Holy Cross Mountains, Poland. Acta Palaeontologica Polonica 45,151-194.

Treasise, G. \& Sarjeant, W.A.S. 1997: The Tracks of Triassic Vertebrates. Fossil Evidence from North-West England. The Stationery Office, London, $204 \mathrm{pp}$.

Manuscript received December 12, 2008

Manuscript accepted April 14, 2009

Editorial handling: Daniel Marty 